\title{
Geographic particulars of the world's population food ration
}

\author{
Ihor Kholoshyn ${ }^{1}$, Liudmyla Burman ${ }^{1}$, Tetiana Nazarenko $^{2}$, Svitlana Mantulenko ${ }^{1, *}$, and Natalia Panteleeva ${ }^{1}$ \\ ${ }^{1}$ Kryvyi Rih State Pedagogical University, 54 Gagarina Ave., Kryvyi Rih, 50086, Ukraine \\ ${ }^{2}$ Institute of Pedagogy of the National Academy of Sciences of Ukraine, 52-D Sichovykh Striltsiv Str., Kyiv, 04053, Ukraine
}

\begin{abstract}
The research of a human food ration is caused by the great social significance in solving the problem of proper supply the population with food in the world countries. The food problem has a most evident geographic character. The world countries having at their disposal various agro-climatic conditions, demographic resources and population growth rates, socio-economic potential, specialization and labor productivity of agriculture production, are essentially distinguished by the food supply level of population and by structural characteristics of food ration. The formation particulars of the world countries population food ration were considered and characterized in the article. The key characteristics and factors of the world population's food ration were analyzed there. The geographic differences of food ration, as well as the world countries typology by distinctive features of food consumption through their division into groups (nutrition types) according to the content and quantity of basic components in food ration were determined in it.
\end{abstract}

\section{Introduction}

The actuality of the food problem research is preconditioned by its great social significance. Under the present conditions the problem is not placed on the same footing as merely a food shortage, the issue of quality, variety and structural balance of consumed food products, as well as their excess consumption and the consequences caused by it, arises acutely.

The food problem has the most evident geographic character. The world countries having at their disposal various agro-climatic conditions, demographic resources and population growth rates, socio-economic potential, specialization and labor productivity of agriculture production, essentially distinguish by the level of population food supply and by structural characteristics of food ration.

Looking for the ways of smoothing the international differences in the population food provision remains the actual direction of socio-economic geography research. At the same time, the old scientific methodology arsenal, having lost its role in explaining the present-day processes, especially at the global level, is not able to disclose the essence of changes, which are taking place. In this connection, a new approach is required for solving the most adequate spatial representation of food problem in the world countries, which demands applying up-todate research methods (geo-information systemtechnologies, mathematics-statistical apparatus, etc.).

The purpose of this research is to determine the main geographic differences in food ration of the world population and analyze the factors of its formation.

\section{Literature review}

The research is based upon the official data of World Health Organization and the UN Food and Agriculture Organization $[1,2]$.

As long-term experience shows, the problem of nutrition has been always notable by its acuteness. From the works of the well-known Persian polymath Ibn Sina we have got evidences about important significance of the study food ration, which was paid to by naturalists and physicians throughout the world.

Hence, truly scientific interest to food as a part of a nation's culture emerged in the second half of the XIX century. In the works of this period a factual-descriptive approach prevails. Some piecemeal information about food ration of this or that nation could be found in the works of I. Zabelin, N. Kostomarov [3] and others.

The formation of the theoretic-methodological line in the study of food ration as the world nations cultural phenomenon is linked with the research activities of C. Lévi-Strauss [4], R. Bart [5], J. de Kastro [6], V. Pokhliobkin [7], V. Nikolenko [8], V. Smoliar [9] and others. Observations of food ration in the world different regions allowed considering it as a culture's specific sphere that exists in relations of mutually associated historic-geographical, social and cultural context.

Geographic trend in researching food ration of the mankind was developed by J. de Kastro [6], H. Kariel [10], J.-R. Pitte [11], D. Bell [12], A. Colombino [13], P. Mullie [14], T. Lallukka [15], M. Sorre [16]. Various approaches to defining the typology of countries and regions with relation to their population's food ration character, were proposed by the researchers. Thus,

${ }^{*}$ Corresponding author:mantulenkokdpu@ukr.net 
H. Kariel compiled the world map distinguishing "wheat", "rice", "maize", "millet-sorghum" and some other nutrition types of less importance and the corresponding legend to it having determined the main sources of calories and the main sources of protein for each geographic "type of nutrition".

But as it is stated by many researchers, the substantial changes in ration and food nourishing value for the world population are taking place under the present-day conditions [17].

This circumstance gives grounds to speak of insufficient study of geographic aspects of territorial food ration differentiation of the world population and the factors that change it. This determines the need of performing further regional exploration of this food problem by geographers.

It is scientifically proved, that the basic components of a human food ration are such nutrients as proteins, fats, carbohydrates, mineral salts, water, microelements and vitamins. Food-staffs contain over 600 nutritive materials that are necessary for normal life activity of human organism, they can be united into four groups: bread and cereals; vegetables and fruit; meat, fish and dairy produce; fatty and sweet foods. Each of these nutrients occupies its place in a biochemical process chain.

Types and traditions of nutrition are the result of long historical an organism adaptation to a particular type of food [18]. In food ration formation of the globe's population a large number of eco- and endogenic processes take place, which can be brought to the following factors: historic-cultural development, climategeographical conditions, religious customs, national traditions, socio-economic development, cultural and trade links, science-and-technical progress, etc.

But at the same time all the variety of food forms intrinsic to the mankind can be put into comparatively small number of nutrition models which are differentiated by the characteristics of the basic sources of calories and animal protein. Within the frames of these models or their combinations there can be featured several nutrition systems which are specific for individual ethnos or historic-ethnographical regions that distinguish by a set of nutrient components [19].

Prompt detection of the steady tendencies in food products structure changing and their consumption causes the need for forming nutrition status of the particular region's population with reference to geographical, climatic and social conditions.

\section{Methods}

The performed analysis of territorial differentiation of the world population food ration was carried out both by using quantitative and qualitative indexes.

There is substantial gap in quantitative food consumption among the world countries (Fig. 1). The most essential gap is between food consumption and nutrition norms in the countries of Asia and Africa. According to the World Bank, over $33 \%$ of population of these countries received less than $1700 \mathrm{kcal} /$ person a day, and the majority of them-below $1500 \mathrm{kcal}$ at the beginning of $1980 \mathrm{~s}$ and $1990 \mathrm{~s}$. Nowadays this figure fluctuates within $1900-2000 \mathrm{kcal}$.

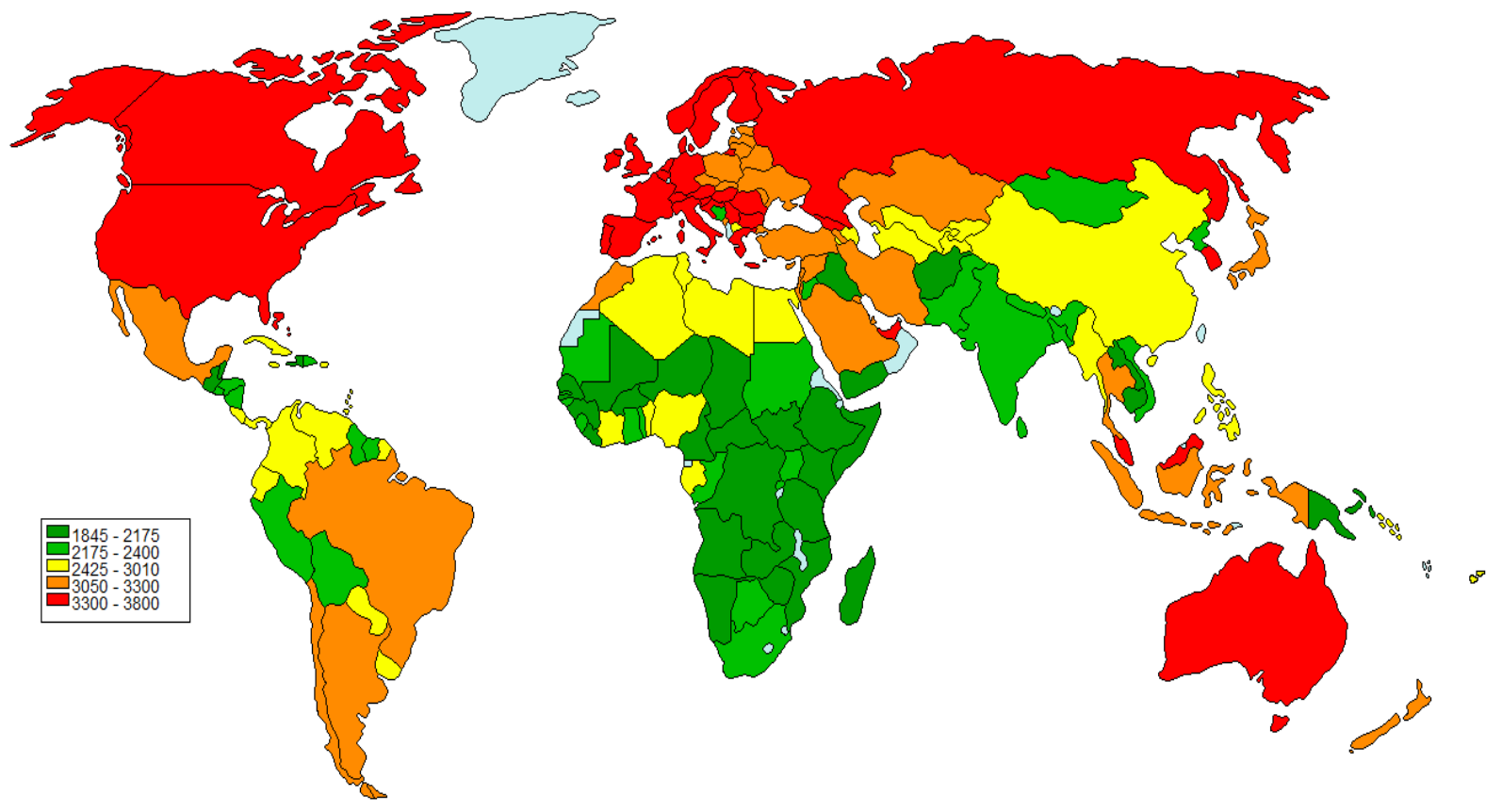

Fig. 1. Daily average per capita food consumption, kcal/person (compiled on FAO data, 2018).

Disproportion in food consumption standards especially considerable if compared to the economically developed countries and the most backward, the poorest ones, primarily in Africa. For instance, the gap in daily average food consumption by Somali population
(1845 kcal/day) and Belgium (3793 kcal/day) is as much as more than twice.

High level of food consumption is typical for economically developed countries at this time. Daily human ration caloric value of food amounts to a little bit 
over than $3000 \mathrm{kcal}$ (except Japan where this index makes up a little more than $2700 \mathrm{kcal} /$ person a day). These countries produce and consume over $3 / 4^{\text {th }}$ of the world food, though only $18 \%$ of the Earth's population live there.

In this connection, in scientific researches a special attention is paid to the fact that more and more people in the world overeat and have body mass overweight, which causes increased susceptibility to diseases, drop in working ability and shortening of lifetime.

The countries with the lowest level of food consumption are located within so-called "hunger belt". Starting in South America, the belt covers larger part of Africa and goes on in Asia.

The epicenter of "hunger belt" is in Tropical Africa, the largest region in the world. The population in a majority of the countries, located on "hunger belt" territory, consume less than $2000 \mathrm{kcal}$ a day, due to this the share of people who suffer from starvation and/or those who are underfed exceeds 40\% (Chad, Somali, Uganda, Mozambique) [20].

Difficult food situation is typical for South-West, South and the South-East Asia. So, in South and SouthEast Asia (except China) food consumption varies from 2000 to $2400 \mathrm{kcal} / \mathrm{day}$.

The world food consumption demonstrates the positive dynamics and has a strong tendency to increase. If in 1930s average per capita consumption amounted from $2100 \mathrm{kcal} /$ day, then before the beginning of 1960s it increased up to 2300 , before the beginning of 1990s - up to 2700 and in 2015 it amounted $2950 \mathrm{kcal} /$ day. Maximum rates of the index growth demonstrate Asian countries, primarily China where the consumption growth made up $45 \%$ as compared to 1970 . For that time, only South Asia countries and African countries to the south of Sahara did not reach daily ration of caloric value, which is specified by FAO as $2400 \mathrm{kcal} /$ person.

More essential is the world countries differentiation by quantitative characteristics of food ration. Thus, by the share of the basic foods ration the characteristics differ almost by four times (from $23 \%$ in Iceland to $81 \%$ in Eritrea), and by the quantity of protein in a ration - by seven times (from $18 \mathrm{~g}$ /day in Iraq to $133 \mathrm{~g} /$ day in Iceland).

Beside high standard values of food consumption, economically developed countries are also characterized by high degree of differentiation of food consuming structure, the index of which is low dependence from basic foods (by caloric capacity this group makes up nearly $30 \%$ of total ration) and high level of animal husbandry products consumption (nearly $30 \%$ of daily caloric capacity as well). Long-term analysis of food consumption in the developed countries testifies unification of consumption structure challenged by mutual transition of national features into the international and vice versa against the background of globalization [21].

At present stage of the society development it is possible to speak of the formation food consumption structure of postindustrial type in the economically developed countries, when qualitative improvement of nutrition takes place through increasing variety of the foods consumed that have higher gustatory and nutritional properties.

Generally, one product dominates in the structure of food ration regarding nutrition of the population in the developing countries, especially in the most backward ones. For instance, for people of South and South-East Asia this is rice, its share amounts to $70 \%$ and even to $90 \%$. For the savannah zone and Sahel in Africa the most typical are millet cultures (chiefly sorghum) which give $40-50 \%$ of daily calorie norm. In food ration of people in African continent's forest zone prevail such root plants as yam, manioc (cassava), sweet potato.

The picture of nutrition of Latin America population is more varied. In the countries with comparatively favorable food balance (Argentina, Uruguay, etc.) the ration base is formed by wheat; in the countries of Central America and in American Indians settling areas maize prevails; in tropical coastal lowlands - rice; in Paraguay manioc; in former "banana" republics of American "isthmus" - banana; in Cuba and Haiti - cane-sugar, etc.

The picture of the world population food ration spatial differentiation is of special interest. In due time, the Soviet geographer A. Voyeikov paid attention to this fact. At various times scientists tried to "fix" and characterize the mentioned types. H. Kariel, for example, compiled a map of territorial localization of the geographic "nutrition types", selected by the basic sources of proteins [10].

At the base of analysis of the world population food ration spatial differentiation, carried out by us, there were laid the main groups of "nutrition pyramid": grain-crops (cereals), products of plant origin (except cereals, they are vegetables and fruit); products of animal origin.

Grain-crops are nutrition base of any civilization. Correspondently, our organism includes more than a half of substances contained in the grain-crops. Precisely to the components contained in grains, our organism has adopted during thousands of years, its digestive system in particular. It is not accidently that man began cultivating grains. Only grain-crops could guarantee communities for survival and health.

The high role of grain-crops in human nutrition and health is determined by high content of amino-acids complex, including indispensable ones, carbohydrates, proteins, vitamins, microelements and other valuable elements. At the same time, the grain-crops cannot replace the products of animal origin, because their proteins are deprived of some important amino-acids. Low caloric capacity of plant origin proteins specifies insufficient food nutrient density among people whose food ration is based on plant edibles. As a result, a stable negative correlation was formed (-0.65 paired correlation coefficient) between the share of grain-crops in population's food ration and food calorie capacity index (Fig. 2).

More than $200 \mathrm{~kg}$ of grains per capita are annually consumed in the countries of the North and Central Africa and most of Asian countries. At the same time in the developed countries of Europe, Northern America and Australia this figure does not exceed $100 \mathrm{~kg}$.

Grain-crops include wheat, rice, maize, barley, rye, oats, sorghum and some local cultures. Their consumption is increasing from year to year (Fig. 2). Hence, out of all 
grains variety the leading place take "the three breads of the mankind": wheat, rice and maize. Though, rice and maize can be called a "bread" rather conditionally taking into account their important food value.

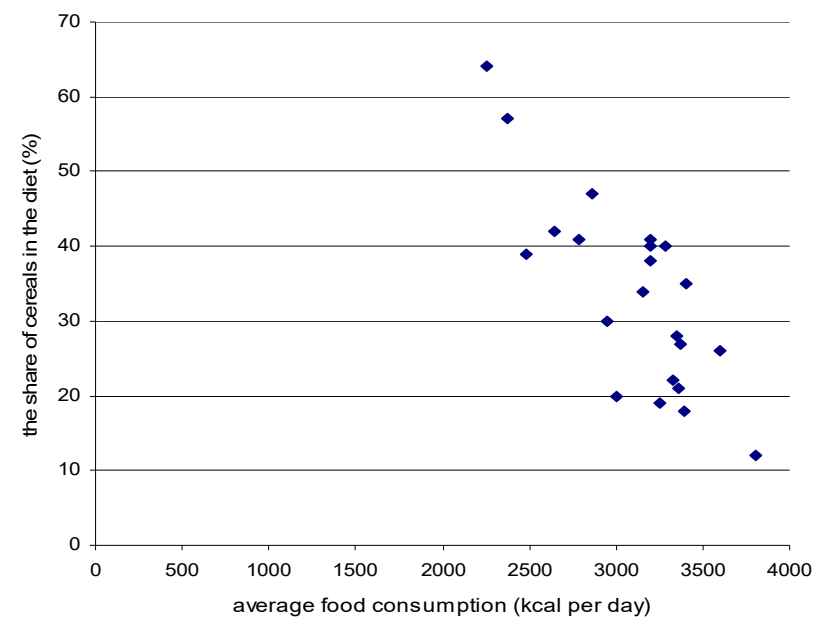

Fig. 2. Correlative interrelation of grain-crops shares in the world population food ration and average food consumption (compiled on FAO data, 2018).

As seen from Fig. 3-4, each of these cultures amounts nearly the third part of total grain-crops consumption in the world population food ration.

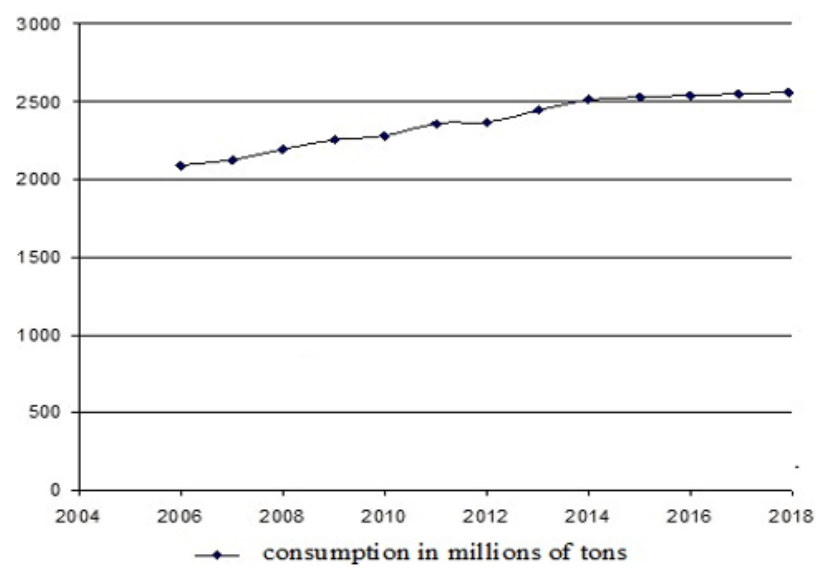

Fig. 3. The world grain-crops consumption.

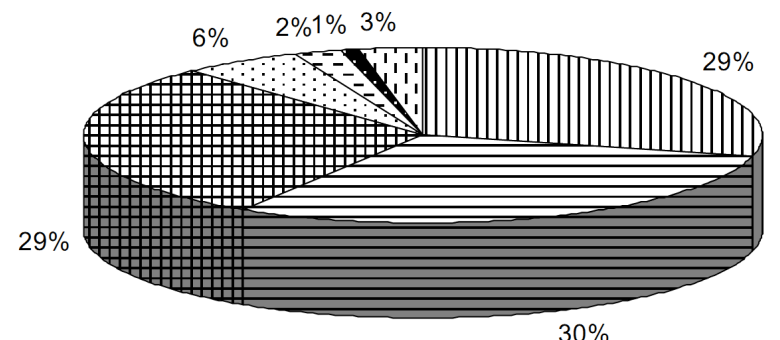

$30 \%$

$\square$ wheat $\boxminus$ rice $\boxplus$ corn $\square$ barley $\square$ rye $\square$ oat $\square$ other cultures

Fig. 4. Structure of grain-crops consumption in the world (right) -2018 data.

Considering the domination of grain-crops in ration of major world nations, their correlation is put in the base of nutrition types classification, offered by H. Kariel. Hence, since the time of elaborating this classification the essential changes in the world population food ration have taken place, causing the need of illustrating its presentday status (Fig. 5).

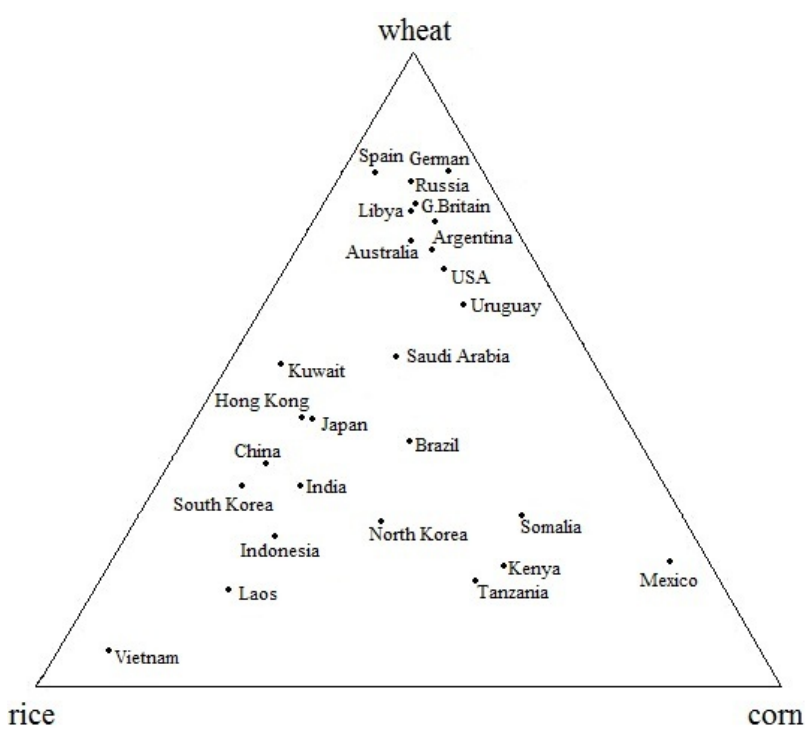

Fig. 5. Correlation of the main grain-crops in the world population food ration (compiled on FAO data, 2018).

As the diagram shows, wheat dominates in food ration in most European countries (Germany, Spain, Great Britain, Russia and others), as well as American ones (the USA, Canada, Argentina and others), and in the countries of different socio-economic types, and Australia too. Livia and Egypt make an exception. The specific rice ration prevails in Asian countries (Vietnam, Laos, Indonesia and others).

Maize is the basic nutrition component in Mexico and in number of South America countries (Guatemala, Honduras, Panama and others) and in East Africa (Somali, Tanzania, Kenia). The countries which have approximately the same ratio of the three types of grains Brazil, Saudi Arabia, Japan, South Korea, Cuba and a number of others which are geographically dispersed.

So, the main geographic feature at present-day stage of grain-crops consumption is a change in the way of equalizing the role of each grains type in the world population food ration. The major reason for this is, evidently globalization and the imposed by it the tastes unification for population in the world different countries.

Fruit and vegetables are the most useful nutrients for human organism. Unlike animal nutrients and fish, vegetables almost completely do not contain fats. Really, neither root plants, nor green plant parts, practically contain oils and fatty acids. This allows including them into food ration practically at unlimited quantities.

The importance of these nutrients in the world population food ration varies within a large range: from $275 \mathrm{~kg} /$ person in Greece to $6 \mathrm{~kg} /$ person in Mozambique as to vegetables, and from $317 \mathrm{~kg} /$ person in Dominica to $1.3 \mathrm{~kg} /$ person in Eriteria as to fruit. The main reason for this gradation is nature-climatic conditions of the countries. The exception makes the economically developed countries that provide themselves with fruit 
and vegetables owing to import. In spite of the positive dynamics of the world fruit and vegetables consumption (vegetables consumption rates growth amount approximately to $5 \%$ a year, and fruit $3 \%$ of that), in food ration of the grown-up population this index is practically as twice less as the minimum recommended by the WHO.

\section{Results}

The spatial analysis performed by us, revealed the following tendencies in indexes spatial differentiation of the world fruit and vegetables consumption:

- the most fruit (over $120 \mathrm{~kg} /$ person) are consumed in economically developed countries and in some other developing countries situated in tropical and sub-tropical belts (they are the main exporters of fruit and products of their processing);

- the least fruit (less than $35 \mathrm{~kg} /$ person) is consumed in African countries;

- by the volume of fruit consumption (over $145 \mathrm{~kg} /$ person) take the lead the countries of the Mediterranean and Eastern Asia;

- the least vegetables (less than $34 \mathrm{~kg} /$ person) are included in food ration by the population of Africa (except its northern part), South Asia and the northern part of South America.

As the Bennet's Law [21] states, in the course of a country's well-being growth its population begins replacing nutrients of plant origin for animal-originated food. This results in the substantial changes in habitual food ration of millions of people, which account replacement plant nutrients for food of animal origin. According to FAO statistics [23], since 1960 milk per capita consumption in the developing countries have increased by twice, meat - by three times and eggs - by five times. Correspondently, the world demand for these products substantially increased for the last fifty years. Moreover, by expert assessment, by the middle of the running century, the growth rates of the demand for protein nutrients will not only stop, but will essentially increase.

Food of animal origin is the food, which a human gets directly from animals or in the course of its further processing. Food of animal origin includes meat, fish, seafood, shrimps, crustaceans, milk, dairy produce, eggs, caviar. These products are a source of biologically important proteins, saturated fats, B group vitamins, fatsoluble vitamins, phosphorus as well as ferrous. Hence, by no means all the population on the Earth have a possibility to get all the vitally nutrients contained in foods of animal origin.

The maximum food of animal origin consumption (over $1100 \mathrm{kcal}$ of daily ration) is marked in the countries of Europe, North America and Australia and the minimum (below $200 \mathrm{kcal}$ of daily ration) - in Africa and_SouthWest Asia. This is one of the severe reasons of hunger in the countries of Asia and Africa. The meat content in food ration of population and the level of food consumption correlate positively at high (0.74) (Fig. 6). The very nutrients of animal origin can ensure the required norm of food consumption for the planet population.

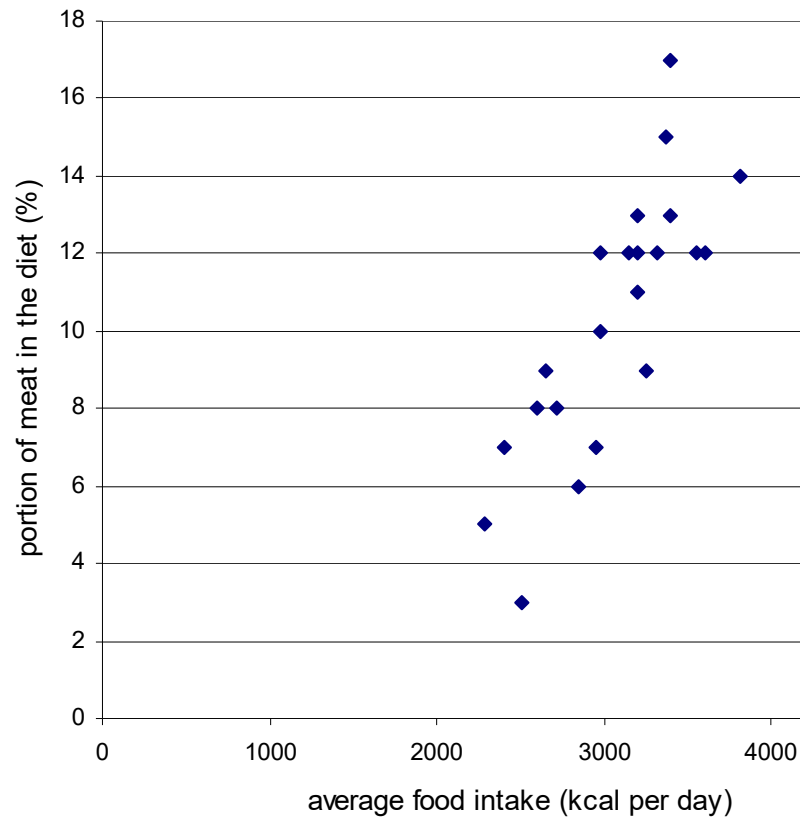

Fig. 6. Correlation of meat share in the world population food ration and the average food consumption (compiled on FAO data, 2018).

Analyzing spatial disproportions in food of animal origin consumption, we came up to the following conclusions:

- maximum meat consumption (over $80 \mathrm{~kg} /$ person a year) is found in the economically developed countries of Europe, North America and in Australia (except of Brazil and Mongolia), and minimum meat consumption (from 3 up to $10 \mathrm{~kg} /$ person a year) - in South and West Africa, and also in the major part of South-East Asia;

- milk and dairy produce dominate (more than $224 \mathrm{~kg} /$ person a year) in food ration of population in the USA, Australia and in the highly developed countries of Europe, at the same time, in the ration of inhabitants of Central Africa and South-East Asia they are practically absent (less than $15 \mathrm{~kg} /$ person a year);

- in food ration of the USA population, the most of countries of Europe and China the quantity of eggs exceeds $12 \mathrm{~kg} / \mathrm{person}$ a year, and in Central Africa they are less than $1 \mathrm{~kg} /$ person a year.

So, in view of the dynamic processes in meat produce consumption which has been noted for the last 10 years, it is possible to say for sure that a large quantity of meat consumption per capita in the developed countries is quite typical during many years, therefore, the growth will be minimal. But in South-East Asia that has recently got economical possibility of purchasing meat protein nutrients, the amount of meat consumed will have increased by more than three times by 2050: from 3$10 \mathrm{~kg} /$ person a year to $30 \mathrm{~kg} /$ person a year. In this way, Asian countries are taking leadership by the rates of increasing demand for protein produce, in the first turn for meat.

With regard to the fact that the world population food ration specificity forms the ratio of nutrients mentioned above three basic components of the "nutrition pyramid", we developed classification of nutrition types, which is grounded on quantitative indexes in grain-crops ration, 
plant origin products (without taking into account grains) and food of animal origin (Fig. 2, 6). The classification takes into account not only basic structure of food ration, but its quantitative consumption as well.

For this purpose, statistics selection for each component was broken into groups on the principle of evenly tight intervals for three groups with minimal medium and maximum values. The marginal index values are shown in Table 1.

Table 1. The marginal index values of the basic structure components in the world's population food ration.

\begin{tabular}{|c|c|c|c|}
\hline Groups & $\begin{array}{c}\text { Grain-crops } \\
\text { (kg/person) }\end{array}$ & $\begin{array}{c}\text { Food of plant } \\
\text { origin } \\
\text { (kg/person) }\end{array}$ & $\begin{array}{c}\text { Food of animal } \\
\text { origin } \\
\text { (kg/person) }\end{array}$ \\
\hline Minimal & below 134 & below 110 & below 76 \\
\hline Medium & $\begin{array}{c}\text { from } 134 \text { to } \\
180\end{array}$ & from 110 to 185 & from 76 to 182 \\
\hline High & over 180 & over 185 & over 182 \\
\hline
\end{tabular}

Map-making of spatial distribution of base components of the world's population food ration was carried out by the selected indexes. When overlapping cartographical layers (over-lineal operation), the typology of countries for their food consumption particulars through their distribution into groups (nutrition types) of basic components structure in food ration was made (Table 2, Fig. 7).

Table 2. The world's population food ration types classification by nutrition structure basic components.

\begin{tabular}{|c|c|c|c|}
\hline $\begin{array}{c}\text { Food ration } \\
\text { types }\end{array}$ & Grain-crops & $\begin{array}{c}\text { Food of } \\
\text { plant origin }\end{array}$ & $\begin{array}{c}\text { Food of } \\
\text { animal origin }\end{array}$ \\
\hline 1 & low & high & high \\
\hline 2 & medium & high & high \\
\hline 3 & medium, high & high & medium \\
\hline 4 & low, medium & medium & high \\
\hline 5 & medium, high & medium & medium \\
\hline 6 & medium, high & medium & low \\
\hline 7 & medium, high & low & medium \\
\hline 8 & high & low & low \\
\hline 9 & low, medium & low & low \\
\hline
\end{tabular}

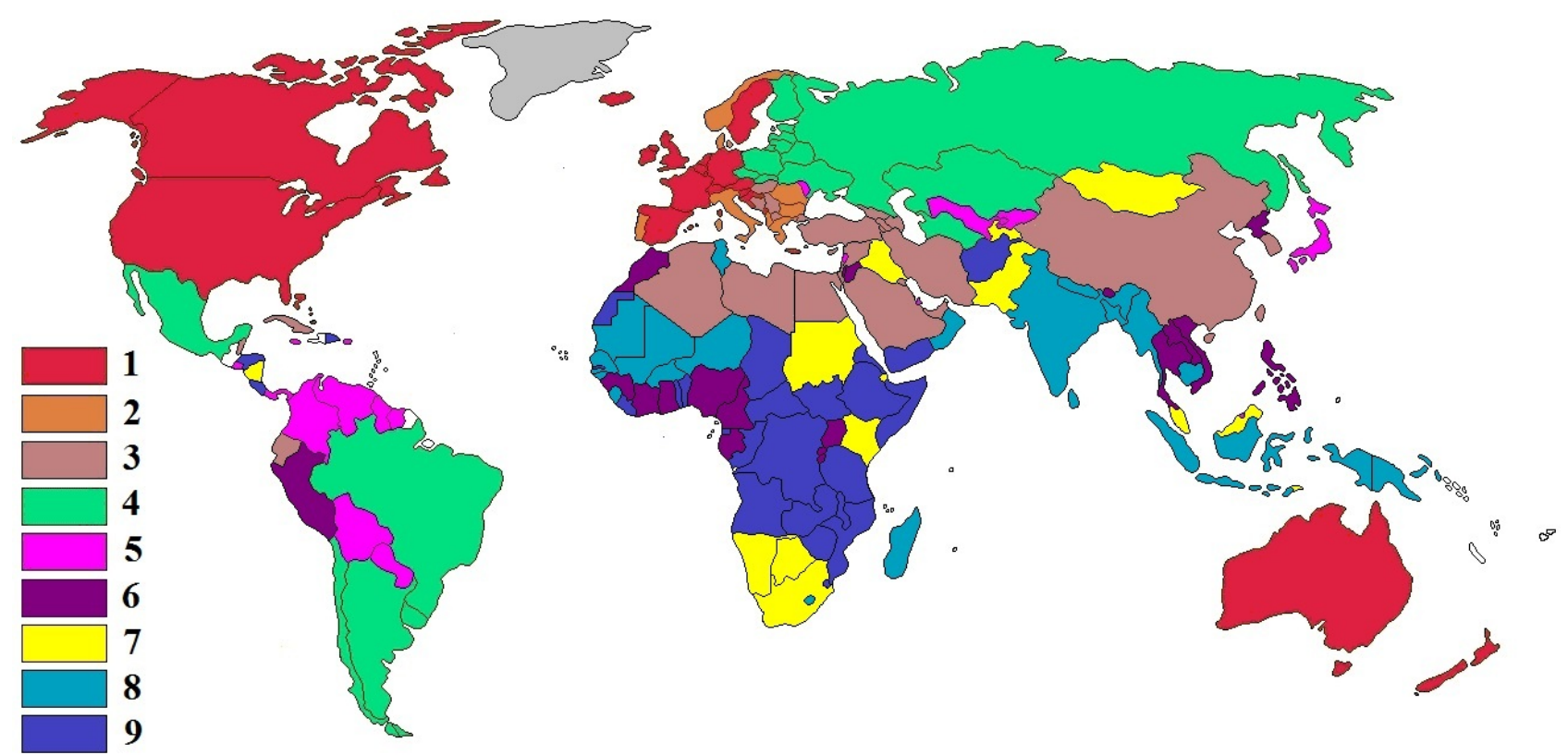

Fig. 7. Distribution of the world's population food ration types (according to classification shown in Tables 1,2).

The world population food ration types brief characteristics in territorial groups will be given.

The first type includes the countries with unbalanced food situation. The majority of West Europe countries, the USA, Canada, New Zealand and Australia are among them. Common feature of these countries population food ration is a hypertrophied level of consumption by the number of calories (over $3400 \mathrm{kcal} /$ person a day). It differs structurally by low norms of grain-crops consumption at rather high rates of plant and animal origin nutrients consumption. High level of fats consumption (over 30\%) is a characteristic feature for countries of this type. This unbalanced nutrition causes spreading among the population of the said countries so-called "diseases of rich countries" such as cardiovascular diseases, obesity, etc.

Food ration of the second type is characterized by nutrition high balance at rather high level of food consumption (from 3200 to $3400 \mathrm{kcal} /$ person a day). This is achieved for the account of using seafood for nutrition, because all these countries (Greece, Italy, Portugal, Albania and others) have access to the sea. Moreover, the role of grain-crops in ration increases, which is determined by cultural-historic development of these regions.

The countries of the third food ration type at this time have reached normal values (in FAO view) of daily ration caloric capacity $-2600-3100 \mathrm{kcal} /$ person a day. This is 
caused by some decrease of animal origin food content at high share of vegetables and fruit. Grain-crops are gaining in considerable importance. The countries with rather favorable food situation are referred to it. They are the countries of North Africa (Egypt, Livia, Algeria), the most developed Asian countries (Saudi Arabia, China, UAE, Turkey and others), and some European developing countries as well (Macedonia, Bosnia and Herzegovina and others).

The countries of the fourth food ration type are characterized by high consumption level values - the average daily ration caloric capacity amounts nearly $3100 \mathrm{kcal} /$ person. They most the post-Soviet countries (Russia, Ukraine, Belorussia, Kazakhstan, Estonia and others), a number of European countries (Czech Republic, Slovakia, Finland), and the most developed Latin American states (Mexica, Argentina, Brazil, etc.). The majority of these countries solve the food problem at the account of their own resources. Nutrients of animal origin dominate in food ration at average values of grains, vegetables and fruit content.

Food ration of the fifth type is characterized by the most food consumption structure differentiation. It can be called as ration of "nutrition balance". At the average content of all basic components, the level of food consumption fluctuates within the range of $2500-3000$ $\mathrm{kcal} /$ person a day. With the exception of Japan, they are the countries of lower level of economic development due to more limited resources for food import. They are mainly Latin American (Venezuela, Columbia, Paraguay and others) and Asian (Kyrgyzstan, Lebanon, Uzbekistan and others) developing countries.

Food ration of the sixth and seventh types is specified among the population with food situation at the stage, which is normalizing. Yet, some years ago, the problem of hunger was the most actual in these countries. The difference among them is connected mainly with a bigger share of animal nutrients in ration of the seventh type, which is compensated by stable-medium quantity content of vegetables and fruit in ration of the sixth type. In this regard the countries achieved acceptable values of ration caloric capacity (from 2100 to $2500 \mathrm{kcal} /$ person a day). The sixth nutrition type includes mainly the countries of West Africa (Ghana, Nigeria, Côte d'Ivoire and others) and Indo-China peninsula (Vietnam, Laos, Thailand and others). The countries with food ration of the seventh type are territorially re-dispersed. It is to the south and east of Africa (SAR, Namibia, Botswana) and South and Central Asia as well (Mongolia, Pakistan, Malaya and others).

The countries with food ration of the eighth and ninth types are the ones suffering of food crisis. Daily ration caloric capacity values make up less than 2200 to $2500 \mathrm{kcal} / \mathrm{person}$ for the eighth type, and less than $2000 \mathrm{kcal} /$ person a day correspondently. Higher food ration values of the eighth type are conditioned by compensation of the shortage of basic nutrition components for higher content of such grain-crops as wheat and rice. The ration base for population with the ninth nutrition type are millet-crops (sorghum, first of all) providing with $40 \%$ of calories and rood plants.

Food problem solving in these countries is not possible without involvement of international organizations. The group includes the majority of Central and East African countries and the number of South and South-East Asia states.

\section{Conclusion}

So, in the result of the complex geographic researches the world countries typology by food consumption characteristics through their division into groups (nutrition types) relating to food ration basic components was carried out. The proposed methodology of differentiating population food ration types can be considered as one of the instruments for monitoring the dynamic processes of providing the mankind with food nutrients and developing the ways of solving food problem in the world.

The authors consider further research of this problem in analyzing geography of physical food nutrients accessibility, which assumes studying the basic food produce availability for population in countries or regions in amount and assortment corresponding to the prescribed rational norms of consumption, needed for providing health and human active life.

\section{References}

1. World Health Organization, https://www.who.int (2020). Accessed 11 Feb 2020

2. Food and Agriculture Organization of the United Nations. Food and agriculture data (2020), http://www.fao.org/faostat. Accessed 11 Feb 2020

3. N. Kostomarov, I.Ye. Zabelin, Ozhizni, byte $i$ nravakh russkogo naroda (About life and customs of the Russian people). (Prosvescheniye, Moskva, 1996), p. 234

4. C. Lévi-Strauss, Anthropologie structural (Penguin, New York, 1978), p. 383

5. R. Bart, Osnovy semiologii (Basics of semiology). (Progressor, Moskva, 1975), pp. 114-163

6. J. de Castro, Geografiya goloda (The geography of hunger). (Izdatelstvo inostrannoy literatury, Moskva, 1954), p. 88

7. V. Pokhliobkin, Nacionalnye kukhni nashikh narodov. Osnovnye napravleniya, ikh istoriya $i$ osobennosti. Receptura (National cuisines of our peoples. Main directions, their history and features. Recipe). (Agropromizdat, Moskva, 1991), p. 608

8. V. Nikolenko, Hastronomichna kultura suspilstva: teoretyko-metodolohichni zasady analizu (Gastronomic culture of society: theoretical and methodological principles of analysis), vol. 993 (KhNU imeni V.N. Karazina, Kharkiv, 2012), pp. 44-48

9. V. Smoliar, Racionalnoe pitanie (Rational nutrition). (Naukova dumka, Kyiv, 1991), p. 368

10. H.G. Kariel, A proposed classification of diet. Annals of the Association of American Geographers 56(1), 
68-79 (1966). doi:10.1111/j.1467-

8306.1966.tb00544.x

11. J.-R. Pitte, Gastronomie française: histoire et géographie d'une passion (Fayard, Paris, 1991), p. 265

12. D. Bell, G. Valentine, Consuming Geographies: We Are Where We Eat (Routledge, London, 1997), p. 256

13. A. Colombino, The geography of food. Bollettino della Società Geografica Italiana VII (2014), 647656

14. P. Mullie, P. Clarys, M. Hulens, G. Vansant, Dietary patterns and socioeconomic position. Eur. J. Clin. Nutr. 64(3), 231-238 (2010). doi:10.1038/ejen.2009.145

15. T. Lallukka, M. Laaksonen, O. Rahkonen, E. Roos, E. Lahelma, Multiple socio-economic circumstances and healthy food habits. Eur. J. Clin. Nutr. 61(6), 701-710 (2007). doi:10.1038/sj.ejcn.1602583

16. M. Sorre, The geography of diet, in Reading in Cultural Geography (University of Chicago Press, Chicago, 1962), pp. 445-456.

17. I. Kuzina, A. Naumov, Agrogeografiya mira (Agrogeography of the world). (Izdatelstvo Moskovskogo universiteta, Moskva, 2004), p. 128

18. A. Kozlov, Pischa ludey (Human food). (Vek 2, Friazino, 2005), p. 272

19. G. Vechkanov, Kachestvo zhyzni naseleniya kak priznak sostoyania obschestva (The quality of people life as a sign of the state of society). (SPbGIEU, Sankt-Peterburg, 2012), p. 314

20. V. Maksakovskiy, Geograficheskaya kartina mira. Kniga I: Obschaya kharakteristika mira (Geographical picture of the world. Book I: General description of the world). (Drofa, Moskva, 2008), p. 495

21. M. Kapkan, Dissertation, Ural State University named after A. M. Gorky, 2010

22. N. Starikov, Dissertation, Moscow State University named after M. Lomonosov, 2016

23. World Food Programme (2020), https://www.wfp.org. Accessed 11 Feb 2020 